\title{
LA LINGÜÍSTICA DE NUESTRO TIEMPO
}

DOI: 10.17057/fmfhv.2021.014

Texto inédito, sen datar. Consérvase nunha copia lacunar. Arquivo familiar. 

A mediados del siglo pasado surgió en Galicia un importante movimiento lingüístico que procuró con entusiasmo la exaltación del estudio de la lengua nacional, la publicación de obras muy estimadas en su tiempo, la creación de la Real Academia Gallega y la difusión de problemas que aún hoy siguen apasionando.

Tenía como precursor al P. Sarmiento, un extraordinario fenómeno de intuición lingüística, pero se canalizó en muy diversos sentidos.

Esquematizando el proceso, podemos considerarlo obedeciendo a dos direcciones fundamentales. Se tiende por un lado a deshacer la leyenda negra de Galicia exaltando con lirismos y ajenas historias el desarrollo literario del gallego, y por otro a convertir esta lengua en instrumento literario conforme a las ideas entonces imperantes.

Sin estos fines preconcebidos, la labor de nuestros precursores hubiera sido de gran provecho y, por añadidura, los hubiera alcanzado plenamente. El espíritu de trabajo de D. Antonio de la Iglesia, de Cubeiro [sic] o de D. Andrés Martínez Salazar, sin estas preocupaciones ideológicas, quizás inevitables y necesarias, hubiera llevado a cabo fácilmente la publicación esmerada de todos los textos antiguos de Galicia, provistos de minuciosos vocabularios. Hacia el año 1900 habían encontrado el verdadero camino, pero se hallaban al final de su carrera y sin gentes que pudieran continuar su labor.

Con relación a la lengua viva cabía esperar otro tanto de Valladares y Saco Arce, por no citar más que a las principales cabezas. De no haberse enredado en los criterios de corrección que ya empezaban a estar caducados, nos hubieran legado un verdadero tesoro lingüístico del que a estas horas habrán desaparecido no pocas piezas. Apresurémonos, sin embargo, a agradecer a todos ellos lo que les debemos y que tal vez no podamos superar, y muy especialmente el espíritu de dedicación que sintieron por su tierra, en la que sin duda nadie les aventajará.

Las ideas no se presentan con claridad hasta después de darles muchas vueltas. Hasta el momento actual de la lingüística se creyó que las lenguas eran seres 
vivos, con su origen, culminación y final concretos. Alcanzada la perfección, toda variación era decadencia. Bopp y Humboldt eran de esta opinión y nuestros lingüistas no podían pensar de otro modo.

La preocupación que dominó a un gran sector fué la de demostrar la excelencia y dignidad del gallego, para lo que creyeron necesario remontarlo en unos siglos sobre el castellano. Abandonaron con ello el estudio metódico de los documentos, limitándolo a aquellos que les servían para sus fines y olvidando aun en estos casos los más elementales principios de crítica.

Otro sector se hallaba preocupado con afanes pedagógicos. Se pretendía crear una lengua literaria, no arbitraria por cierto, sino creada en una apreciable labor de observación directa. La labor meritísima de los iniciadores, sin embargo, emprendida bajo un signo de corrección imposible (...) fácilmente por los continuadores $(. . .)^{1}$ al ver que sus estudios toman una dirección nueva y marginan incluso aspectos que se venían teniendo como fundamentales, nos parece oportuno dar aquí unas notas sobre estas direcciones y su capital importancia.

Por doloroso que resulte, debemos partir del hecho de que los estudios sobre una lengua no influyen para bien ni para mal en su vitalidad y desarrollo. Una lengua no se extiende o arrincona porque disponga o no de gramáticas y diccionarios perfectos. La vida de las lenguas, su desarrollo y desaparición es verdad que son objeto del estudio de la lingüística, pero ésta no puede provocar su vigencia como medio de expresión. Las lenguas son el resultado de fenómenos históricos que sería ridículo pretender controlar desde el campo de la lingüística. Cuando estos fenómenos favorecen el desarrollo de una lengua, la tornan necesaria para un mayor número de individuos — como ocurre actualmente con el inglés-; las gramáticas y diccionarios son sin duda un auxiliar precioso para el extranjero que quiera asimilársela, pero nada más.

Fuera de este caso, el estudio de una lengua tiene el mismo carácter abstracto que el de la historia o de la economía de un país. Los resultados prácticos que de estos estudios puedan derivarse son ajenos a los mismos y no puede en forma alguna preverlos ni provocarlos el investigador.

1 Segue unha lagoa de, polo menos, trinta liñas. 
Sé que desencantará esto a algunos espíritus generosos que quisieran para el gallego el imperio espiritual a que su brillante historia parece darle derecho. Pero los hechos de la lengua no se rigen por otros hados más benignos que los de otra fortuna.

Sin este objetivo, por otra parte, hay bastantes razones que justifiquen todo el entusiasmo que en dichos estudios quiera ponerse. El estudio del gallego, limpio de todo móvil extralingüístico, por noble que sea, tendrá grandes repercusiones de todo orden en el estudio de la historia gallega en general, pero muy particularmente en el de la historia de la lengua madre. Los maestros que hoy dirigen espiritualmente los estudios de la lingüística gallega son grandes romanistas. Su objeto no es otro que el de incorporar la gramática del gallego en el cuadro comparativo de las lenguas románicas, sobre el que se irá levantando el verdadero perfil del latín vulgar del que todas se desprendieron.

Menos íntima, tal vez, no es menos noble y generosa esta tarea que la emprendida por nuestros antepasados. 